\title{
Recruiting for Librarianship: One Program
}

Recruit, v.t. . . . 1. To strengthen or supply with new men or troops; to fill up by enlistment; also, to muster; raise. 2. To provide with what is needed to correct or prevent exhaustion, etc.; replenish. ... Webster's New Collegiate Dictionary, 1956.

$\mathrm{A}$ S THE ABOVE TITLE has been carefully worded to indicate, the following is a description of one university library recruitment program. No claim is made of uniqueness, or even of special originality. This is not necessarily the program.

It is, however, a program that is both practicable and apparently effective. Because the writer believes that a description of the workings of an actual operating recruitment program-even one as new and modest as is Missouri's - should be of interest and value to others, it is offered for consideration, emulation perhaps, and/or criticism.

\section{BACKGROUND}

The recruitment program of the University of Missouri Library was launched officially early in January, 1957. Begun after a series of discussions between Dr. Ralph H. Parker, university librarian, and the writer, it was conceived to be this library's initial and still somewhat tentative contribution toward a solution to that recognized urgent and widespread need for more librarians-librarians of all specialties, in all types and sizes of libraries, in all parts of this country and abroad.

Various recruitment methods were considered during these discussions. Some were rejected. Some were modified

$M r$. Blackburn is assistant to the librarian, University of Missouri Library. to meet the demands of practicality. Some were accepted as proposed. The final result was our program as it will be described. Whether it will remain our program is as yet problematical. Time, future developments, criticism, further ideas - these will be among the guiding factors.

\section{Purpose}

The purpose of the recruitment program of the University of Missouri Library is twofold: (1) primarily, to present a "message of librarianship" to all those who might be deemed desirable and qualified recruits for the profession, in any capacity, anywhere, and (2) secondarily and indirectly, the possible recruiting of future professional staff members for the University of Missouri Library.

It is, then, a program designed to acquaint promising young people of college age with a knowledge, not only of the shortage of qualified personnel within the profession, but of the values, challenges, and inherent rewards (material, intellectual, and spiritual) of a career in librarianship - with the hope that, because of this acquaintance, some at least of these potential recruits will become, sooner or later, actual ones. To that end, no particular library specialty is stressed; no one type of library is emphasized at the expense of other types; no single library school is recommended over all other schools.

\section{SCOPE}

This program, yet in its veriest infancy, is contenting itself for the present at least with modest scope. Believing that recruitment (as so many other things) can best be started "at home," its field of operations has been limited 
to those university students working as assistants within the library, to clerical and sub-professional personnel on the staff, and to such persons (probably students) who may come to the library requesting information and/or guidance concerning a career in librarianship.

Its scope is limited even further. Student assistants and junior staff members are carefully screened, both by the various immediate supervisors and by the assistant to the librarian. Consideration is given to work-evaluation reports, scholastic averages, and personality factors. However serious the shortage of librarians may be, it is believed that only stable, intelligent, and purposeful individuals should be recruited, and at such the program is directed. Neither the university librarian, nor his assistant have more than limited time to devote to such a program-however worthy, important, and stimulating it may be.

But granting all this - that the campaign is newly started, that its scope is modest, that much more could be donethis program has, through tentative results which can be cited as evidence, already proved to be within its limitations an effective and successful one.

\section{METHODS}

Of what does this program consist? What, specifically, are we doing at present? What do we plan to do in the future?

First of all, there has been set up within our graduated pay scale for student assistants a provision for recognizing and rewarding an individual student assistant's undergraduate study of library science. This scale previously had been based solely on class standing and work experience. Now, an additional five cents an hour is paid for each five hours of acceptable and properly certified credit in library science-whether earned in the Department of Library Science, University of Missouri, or at any other col- lege or university with such a department.

The purposes of this provision are varied and probably apparent: (1) to reward student assistants interested enough in library work to have already studied library science. (Obviously, an informed and interested library assistant is a better assistant; familiar with at least some of the tools and terminology of the profession, he is logically worth more money.) (2) to stimulate, perhaps, additional (even though, at first, possibly only monetary) interest in undergraduate library science, as offered by the University's Department; (3) to nourish, if possible, latent, budding, or even potential interest in librarianship as a career-even though such tentative interest may not result in immediate study; (4) to present, in short, in one simple and relatively cost-free way, evidence of the $\mathrm{Li}$ brary's belief in the importance and value - to it and to the individual - of the study of library science.

The results? It is yet too early to say. At present, only two student assistants (both girls) are benefiting from increased hourly wages as a result of prior study. A few student assistants have enrolled, probably at least in part because of this provision, for such study this semester. So, though there has been to date no evidence of a stampede converging upon the doors of the local Department of $\mathrm{Li}$ brary Science, there is, we feel, some hope. Other student assistants may enroll in library science courses because of this provision; some few student assistants may even, in time, decide to become librarians as a result of this introduction to the profession. In any event, it is costing the library little to be optimistic.

But important though it may prove in the long run, the provision described above is at present only a minor and secondary part of our recruitment program; the heart of this program is a talk - a "message for librarianship." This 
talk, which takes place in an informal office atmosphere, is presented by the assistant to the librarian to groups of from four to six individuals. This meeting, as such, normally lasts from one and one-half to two hours. The talk itself consumes perhaps an hour; the remaining time is devoted to a question and answer period and/or round-table discussion.

This talk is intended to accomplish one simple thing: to direct, if possible, with dignity and without a "hard sell," the thoughts of these potential library school recruits towards librarianship as a career. To this end, the assistant to the librarian points out, among other things, the widespread and more-than-serious shortage of qualified personnel within the field, and the resultant opportunities this affords to the new librarian; the challenges, some of the problems yet to be solved; the rewards of the professionmaterial (salaries, security, etc.), intellectual, spiritual. Advice is given on degree requirements and curricula, requisite and/or beneficial preparation (graduate and undergraduate), desirable qualifications and interests. Quotations from prominent librarians, such as Francis St. John and Lawrence Clark Powell among others, are cited. In short, an effort is made to transmit a personal belief that librarianship is an honorable, important, rewarding, satisfying, eminently worthwhile way of life.

That part of the talk completed, the students are told what the University of Missouri Library administrators are prepared, and more than willing to, do if any or all of them should give evidence of even tentative interest in a library career. It is pointed out that there is available for their examination catalogs and other literature from most, if not all, of the accredited library schools; that information concerning scholarships, fellowships and assistantships can be supplied; and that support in every practicable manner will be given to their efforts to secure such financial aid. It is emphasized that every consideration will be given to any one of them who, upon graduation from library school, should choose university library work and express a desire to return to this library, and that, conceivably, we might go to the extent, perhaps, of guaranteeing future professional staff positions to certain exceptionally promising individuals.

In addition to information and promises, an opportunity for varied library experience as a student assistant is offered. It is explained that library work, excluding administration, falls into two general categories: public service and technical processing. Attention is called to the possibility of transferring, upon their request, student assistants from processing to public service, or vice versa, thus enabling them to obtain a preliminary familiarity with both. They are reminded that since the beginning of the 1957 spring semester, student assistants are paid an extra five cents an hour for each five credit hours of undergraduate library science.

A few words of conclusion, and the talk is ended. At this point, any one who may be bored or definitely not interested in librarianship as a career-so certain that librarianship is not for him that he does not care to remain for the question and answer period that follows-is invited to leave. To date, no one has walked out.

The questions asked during the various periods have been numerous, varied, and intelligent. What specific subjects are studied in library school? How many accredited library schools are there? What is their location? Which are considered to rate the highest? Why are language skills so stressed? What of an additional advanced degree in another subject field? Is that year wasted? And, if not, what benefits and/or monetary re- 
wards are likely to stem from such a degree? Can one actually become a professional librarian with one calendar year, or less, of graduate study? These questions, and others, have been asked at almost every meeting.

At the conclusion of the question and answer period, the students are thanked for coming, and appreciation for their courteous and thoughtful reception of the discussion is expressed. They are invited to return individually for further talk, for counsel, or for examination of library literature.

\section{RESULTS}

The results? It should be repeated that the program is new and modest in scope. It should also be repeated that this program already has proved to be within its limitations an effective and successful one. That claim is based on these results.

Our two initial talks were presented in January of this year. Eleven young men and women - nine men, two women -were chosen to be the recipients of our message. Eight of these students were university seniors, two were graduate students, one was a second-year law student. All were, at the time, library student assistants. (Two of the men graduated in February; one with an A.B. degree in English, one with an M.A. in history.) All had been judged intelligent, mature, and purposeful. All had been rated as excellent to superior in their library work assignments. Three of the men had expressed a tentative interest in librarianship previously; the eight remaining individuals were unknown quantities, so to speak, in that respect.

Of the eleven with whom the assistant to the librarian talked at that time, six have returned to his office for further discussion. Three of these six individuals were the young men mentioned immediately above. Of these three, one would now be a law librarian, would enroll in library school after successful completion of his study of law. One is weighing the differences in opportunities and rewards between library school and graduate study in English, and leaning at this time toward the former. The third, now just beginning three years of military service, currently plans to enter library school upon completion of his enlistment in the Navy.

Of the other three who have returned to the assistant's office, one young woman has been accepted for admission this summer to the Department of Library Science, University of Michigan. (A former WAC, Miss S- hopes to return to the Far East. Michigan, because of the oriental studies offered there in conjunction with its program in library science, was her first and obvious choice when she decided upon librarianship as a career.) The second young woman may well enroll in library school after completion of an M.A. degree in English next June. (Miss W-, in her current thinking, would select a school in which a degree can be earned in nine months. Pratt, for this reason and others, is her tentative choice at present.) The young man with the M.A. degree in history has announced the intention of completing library studies, through summer sessions, while teaching high school history throughout the winter months. (Mr. A - has written to both Denver and the University of California. Either, for his purpose, would be an excellent choice.)

In short, eleven persons recruited, six actual or probable recruits - one now enrolled in library school, one definitely decided but not yet enrolled, four in varying stages of decision and/or preparation. And, of these six, three, who, by their own admission, had not previously considered librarianship as a career.

The remaining five of the eleven, the five who have not returned to the office? Who knows? Perhaps a seed has been planted. There is time. 


\section{Future Plans}

Our future plans-what of them? More of the same, with continued emphasis on individual or small group talks with selected potential library recruits. Indeed, we have now (March, 1957) just finished a series of talks with some eighteen outstanding junior-year student assistants, plus two other student assistants - one a senior, one a graduate student. These students were thoughtful, attentive to the message. In a gratifying number, at least tentative interest in librarianship was obviously stimulated. Further than that, one cannot say at present. For most of these students, the time of final decision could well be a year away.

In addition, we plan to expand our field of operations in these specific ways:

1. We will extend these small group talks to include, not only the categories mentioned above, but selected student assistants of lower class standing, in some cases, down to and including freshmen. (More than a few of these students, we believed could be channeled into librarianship if properly approached before their career planning has become solidified. Some students are undecided. Others change plans in midstream, often more than once. Check any representative group of librarians for proof. Here, then, is a fertile field for recruitment.)

2. We will suggest the serious consideration of librarianship as a career in the course of our autumn mass orientation meeting for library student assistants, new and hold-over. (We will discuss briefly the shortage of personnel within the field, the challenges and rewards of librarianship, the undergraduate prerequisites-language skills, betterthan-average grades, etc.-for admission to library school. We will invite interested students to come to the office for further information and/or counsel.)

3 . We will attempt to promote interest in the undergraduate study of library science. (To those considering graduate library studies, we will point out the benefits of an undergraduate minor: an earlier familiarity with professional terminology, tools, philosophy; the possible reduction, by elimination of the preliminary summer session, of required graduate residence at certain library schools. To others, especially those planning to become elementary or secondary school teachers, we will explain the benefits of an undergraduate major, or even of a minor, in library science. The numerous and distinct advantages of a graduate degree will not be dismissed lightly; they will always be pointed out. But there are some with no plan or desire to pursue fifth-year studies. Toward these, then, we will direct the latter facet of this campaign.)

4. We will display posters and other library recruitment literature within the library, with the hope of stimulating interest in librarianship as a career. (Any student, junior faculty member, or visitor, qualified and expressing interest, will be welcomed. Such individuals will be counseled individually, or perhaps invited to participate in a future small group talk such as that described above.)

We will, in other words, do anything honorable, practicable, and reasonably dignified, to promote librarianship as a career to such individuals as might be both a personal success and an asset to the profession.

\section{SUMMARY}

The foregoing, then, has been a description of the recruitment program of the University of Missouri Library. No claim has been or is advanced of uniqueness or even of special originality. Ours is simply one program. But as one practicable and operating program, it should be worthy of consideration by other academic librarians. Methods which have proved effective for us, it would seem, could well prove effective for others.

Modest and limited, but practicablethese are the keynotes of our program. 
For nothing we have done so far has been expensive; our program has cost, in fact, other than a few cents for postage, only time, effort, and enthusiasm. Nothing that we plan to do in the future will be expensive, impossible, or even difficult to achieve. True, the stimulation of interest in the undergraduate study of library science necessarily presupposes the existence of such a department at that institution; but that is but one small part of the over-all program, and one that can easily be omitted.

In short, there is little here that could not be done by any academic library, and done quite possibly better. That applicability is the justification for this article.

\section{Conclusion}

The profession needs recruitment programs; it needs recruiters. It needs librarians to "preach the gospel of librarianship"-and it needs them especially in college and university libraries. In recognition of these needs, our program has been presented for your consideration.

But we here in Missouri have no monopoly on either interest in or ideas about recruiting for librarianship. Other academic libraries may well have similar or better recruitment programs, more deserving than ours of publicity and wide consideration. Perhaps other libraries have been, and are, doing as a matter of course - without fanfare and/ or self-advertisement - what we have thought worthy of publicizing. If so, let them step forward. Ideas on a subject as important as this should be shared, should be made available as common property to all. Again, ours is not necessarily the program.

We are willing to learn. If present plans materialize, what we have learned in the interval will be summarized in a follow-up article a year or so from now.

\section{ARL's Slavic and East European Project}

The chairmen of ARL committees on Slavic and East European affairs have announced the initiation of a study of American library resources and needs in this field. The study, sponsored by ARL, is supervised by its committee on Slavic and East European Studies and conducted in cooperation with the Joint Committee on Slavic Studies of the ACLS and SSRC.

Melville J. Ruggles, vice-president of the Council on Library Resources, Inc., is directing the study. Assisting him is Vaclav Mostecky, professor of library science at Catholic University. They began their work in September and hope to present their findings and recommendations by the summer of 1958. The study will include an evaluation of existing resources, a review of the bibliographical and fiscal problems of procurement, and a survey of pertinent interlibrary aids and services.

ARL and the Joint Committee on Slavic Studies emphasize that this project offers an unusual opportunity to those seeking solutions to the serious problems surrounding the acquisition and handling of materials from Eastern Europe. As most of the data required for this examination are in the possession of librarians and scholars, questionnaires, interviews, and the checking of library holdings against sample lists will be necessary. "The success of the study," states ARL'S announcement of it, "will depend to a great extent upon the cooperation of librarians and scholars who will be asked to respond to these inquiries." 